\title{
A Web-based Geographic Information System Application for Description of American Viticultural Areas in Texas
}

\author{
Elvis A. Takow ${ }^{1}$, Edward W. Hellman ${ }^{2,3,4}$, Andrew G. Birt ${ }^{1}$, \\ Maria D. Tchakerian ${ }^{1}$, and Robert N. Coulson ${ }^{1}$
}

ADDITIONAL INDEX WORDs. grape, spatial analysis, climate, soil

SUMMARY. A geographic information system (GIS) application was developed containing 18 layers of spatially explicit environmental data relevant to characterization of the eight officially recognized American Viticultural Areas (AVAs) for wine grape (Vitis vinifera) production in Texas. GIS climate variables included daily minimum temperature, daily maximum temperature, daily average temperature (TAVG), growing degree days (GDD), ripening period mean temperature (RPMT), annual precipitation, solar radiation, vapor pressure, and number of frost days. Soil attributes were texture, depth, available water capacity, $\mathrm{pH}$, permeability, and bulk density. These data were used to develop interpretative descriptions of Texas AVAs published on the Winegrowing Regions of Texas web site, which also serves as the public portal to the interactive GIS (AVATXIS). Individuals can use AVATXIS to access data and visualize spatial variability on maps to characterize Texas AVAs for any or all of the environmental factors and to examine spatial relationships among factors.

$\mathrm{T}$ The modern wine industry in Texas began in the early 1970 s with the planting of experimental vineyards in the High Plains, Hill Country, and other areas of the state. A nascent wine industry developed shortly thereafter with new vineyard establishment guided, in part, by a feasibility study conducted by Texas A\&M University (Perry and Bowen, 1974). The study systematically analyzed the state for climate, soils, water availability, and risk factors; many of these factors were summarized with hand-drawn maps displaying distribution of a single factor. Maps in this study included aquifers, irrigable soils, degree days, annual minimum temperature, monthly hail days, annual precipitation, growing season precipitation, expected presence of pierce's disease (Xylella fastidiosa), and risk of cotton root rot (Phymatotrichopsis omnivora). A concluding map displayed priority regions for wine grape production potential in Texas.

${ }^{1}$ Knowledge Engineering Laboratory, Department of Entomology, Texas A\&M University, TAMU 2475, College Station, TX 77843

${ }^{2}$ Texas A\&M AgriLife Research \& Extension Center, 1102 East FM 1294, Lubbock, TX 79403

${ }^{3}$ Department of Plant and Soil Science, Texas Tech University, Campus Box 42122, Texas Tech University, Lubbock, TX 79409

${ }^{4}$ Corresponding author. E-mail: ewhellman@ag.tamu. edu.
The few early experimental vineyards of the 1970s have grown into a substantial Texas wine industry today with more than 220 wineries and 330 vineyards. Most of these are located within the eight AVAs of Texas: Bell Mountain, Texas Davis Mountains, Escondido Valley, Fredericksburg in the Texas Hill Country, Texas High Plains, Texas Hill Country, Mesilla Valley, and Texoma (Fig. 1). Improved understanding of the varied environmental conditions existing in these geographically diverse regions will enhance decision making for vineyard management and guide new vineyard site selection, as well as enhance AVA-based wine marketing efforts.

Environmental features of vineyard sites provide the foundation for successful wine grape production and relevant criteria for the characterization of winegrowing regions include climate, soil, and topography. Climate, and specifically temperature, is considered to be the most influential environmental factor, driving the physiology of growth and development of grapevines (Gladstones, 2011). Consequently, climate impacts nearly every step of wine grape production, from initial site and variety selection to the composition of fruit at harvest. Soil, and indirectly the underlying geology, has an influence on grapevine growth primarily through the supply of water and mineral nutrients. Soil properties key to successful grape production were described by White (2009) and include depth, structure and water, strength, chemistry and nutrient supply, and soil organisms. Topographic influences on viticulture include surface drainage of water, cold air drainage, exposure to wind, and the incidence of the sun's rays on the earth's surface (Jones and Hellman, 2003). Elevation has a profound influence on the minimum and maximum temperatures in a vineyard, particularly in hilly and mountainous terrain.

Until recently, environmental data existed in point data or physical maps, but advances in computer technology have made available spatially explicit data describing the environmental conditions relevant to wine grape production. Climate data formerly collected from point-source weather stations is now used in complex interpolative formulas to create continuous coverage digital maps of weather parameters. GIS technology provides a means to assemble spatially explicit data as knowledge-support tools for visualization and analysis of environmental data.

In most GIS software, data are organized in themes as data layers. A layer is a collection of geographically associated variables in a given spatial extent that have similar attributes. GIS systems involve visualizing and comparing many of these layers together in the form of a map. For

\begin{tabular}{llll}
\hline $\begin{array}{l}\text { Units } \\
\text { To convert U.S. to SI, } \\
\text { multiply by }\end{array}$ & U.S. unit & SI unit & $\begin{array}{l}\text { To convert SI to U.S., } \\
\text { multiply by }\end{array}$ \\
\hline 0.4047 & acre(s) & ha & 2.4711 \\
4.1868 & calorie $(\mathrm{s})$ & $\mathrm{J}$ & 0.2388 \\
0.3048 & $\mathrm{ft}$ & $\mathrm{m}$ & 3.2808 \\
2.54 & inch(es) & $\mathrm{cm}$ & 0.3937 \\
100 & $\mathrm{mbar}$ & $\mathrm{Pa}$ & 0.01 \\
1.6093 & $\mathrm{mile}(\mathrm{s})$ & $\mathrm{km}$ & 0.6214 \\
1.7300 & $\mathrm{oz} / \mathrm{inch}^{3}$ & $\mathrm{~g} \cdot \mathrm{cm}^{-3}$ & 0.5780 \\
$\left({ }^{\circ} \mathrm{F}-32\right) \div 1.8$ & ${ }^{\circ} \mathrm{F}$ & ${ }^{\circ} \mathrm{C}$ & $\left({ }^{\circ} \mathrm{C} \times 1.8\right)+32$ \\
& & &
\end{tabular}




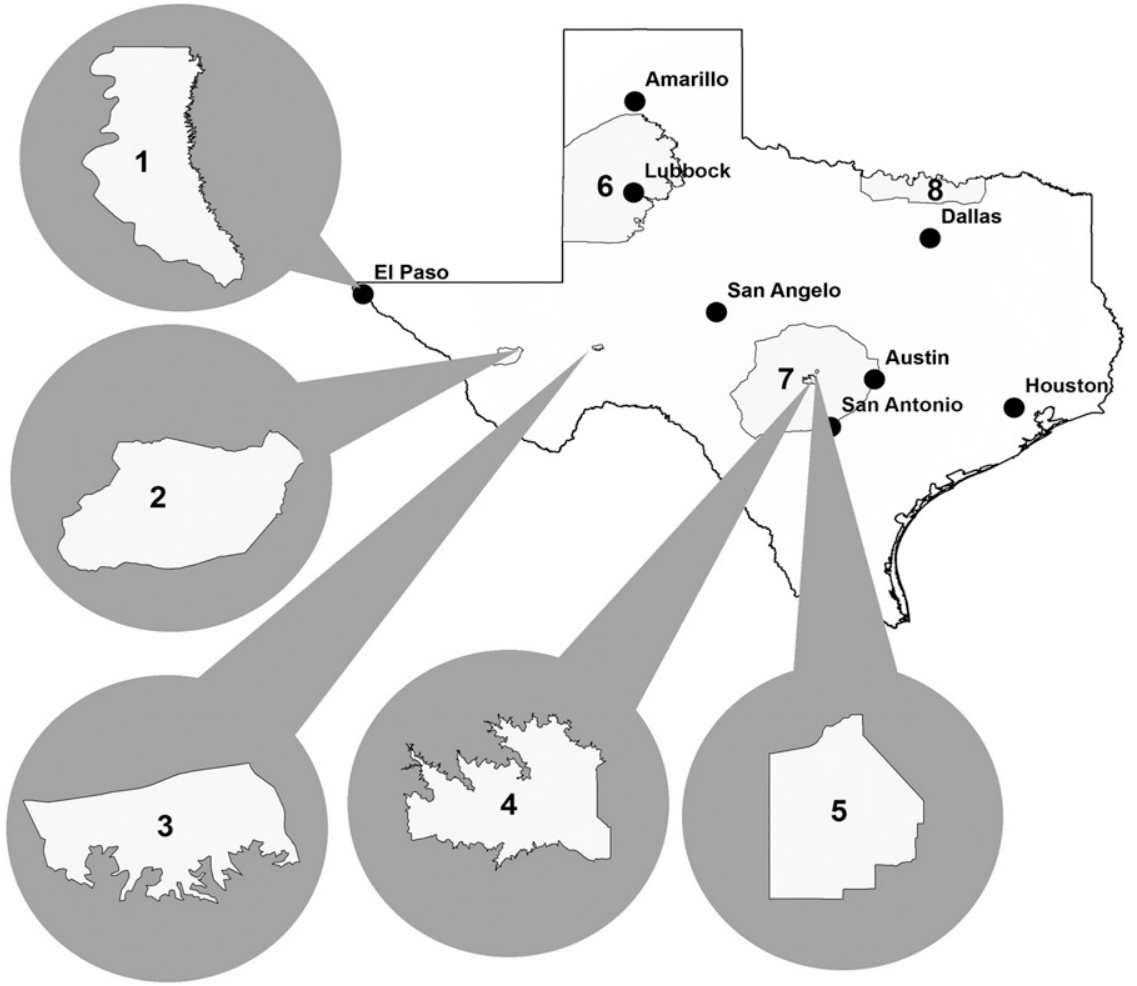

Fig. 1. Geographic distribution of the eight American Viticultural Areas in Texas: 1) Mesilla Valley (Texas portion), 2) Texas Davis Mountains, 3) Escondido Valley, 4) Fredericksburg in the Texas Hill Country, 5) Bell Mountain, 6) Texas High Plains, 7) Texas Hill Country, and 8) Texoma.

example, a GIS system may have one layer containing spatial soil data and another layer containing GDD spatial data. Layers can be classified as either raster or vector, both of which represent different types of data models used in GIS systems. A raster is a continuous spatial data model that defines space as a two-dimensional matrix of equally sized cells (i.e., pixels). A vector is a discrete coordinate-based data model that represents geographic features such as points, lines, or polygons.

The overall goal of our research was to use GIS technology and improved spatial environmental data to develop a publicly available web-based tool for examining the viticulturally important environmental characteristics of the winegrowing regions of Texas. GIS is increasingly used by scientists as a powerful analytical tool to investigate various aspects of environmental spatial variation in relation to viticulture (Blanco-Ward et al., 2007; Bowen et al., 2005; Jones et al., 2010; Nuñez et al., 2011; Park et al., 2011; Reynolds et al., 2007). Viticultural GIS applications providing public access to spatial data are becoming more common; examples include the decision support GIS for vineyard site selection in New York (Lakso et al., 2010) and Pennsylvania (Penn State Cooperative Extension, 2009).

The specific objectives of this research were to 1 ) collect, combine, and assimilate viticulturally relevant climate, soil, and topographic data for Texas; 2) characterize the Texas winegrowing regions by integrating, displaying, and analyzing climate and edaphic factors that affect the performance of vineyards; and 3 ) develop a web-based GIS tool for public access to environmental characterizations of Texas winegrowing regions.

\section{Materials and methods}

Development of the Texas AVA project began with collection of spatially explicit environmental data at the state level. These data were processed and incorporated into the system architecture as 18 custom GIS layers comprising the informational backbone of the Texas GIS system (Table 1 ). Winegrowing region layers were created for each of the eight
Texas AVAs by outlining the boundaries as closed polygons (vector data) using the official AVA descriptions and approved U.S. Geological Survey topographic maps listed in the Code of Federal Regulations (U.S. National Archives and Records Administration, 1985, 1986, 1988, 1992, 1993a, $1993 \mathrm{~b}, 1998,2005)$. All other layers described below were ultimately clipped using ArcMap (version 9.3.1; Esri, Redlands, CA) to correspond to the eight Texas AVA polygons.

Climate data. Data were obtained from Daymet, a collection of algorithms and computer software that interpolate and extrapolate daily meteorological data using digital elevation models (DEMs) and an 18-year data set (1980-97) of daily observations from ground-based meteorological stations (Thornton et al., 1997). The output is a data set of daily temperature, precipitation, humidity, and radiation produced as a continuous surface at $1-\mathrm{km}$ resolution over the conterminous United States. The variables used in this project were daily minimum temperature, daily maximum temperature, TAVG, annual precipitation, solar radiation, vapor pressure, and number of frost days in April and May. Derived indices include GDD as described by Winkler et al. (1974) and RPMT as described by Gladstones (1992). Units of measure and calculation method for climatic variables are presented in Table 2 .

Climate data were sourced by extracting raw data from Daymet for use in ArcGIS (version 9.3.1, Esri). This process involved converting data from an American Standard Code for Information Interchange (ASCII) grid to an Esri grid format, which has enhanced data management capabilities. Complete details on data conversion from ASCII grid to an Esri grid are outlined by Thornton et al. (1997). The grids were further clipped to the area of interest; initially the state of Texas and subsequently the individual AVAs. Climate indices were derived by applying mathematical formulas (Table 2) to each raster layer representative of each AVA using the raster calculator within ArcGIS to calculate values for individual pixels of a given raster.

Soll Data. Two databases exist describing the spatial distribution of soils in the United States-Soil 
Table 1. Data types and data content of the 18 dynamic layers comprising the AVATXIS geographic information system developed to describe the eight American Viticultural Areas (AVAs) of Texas.

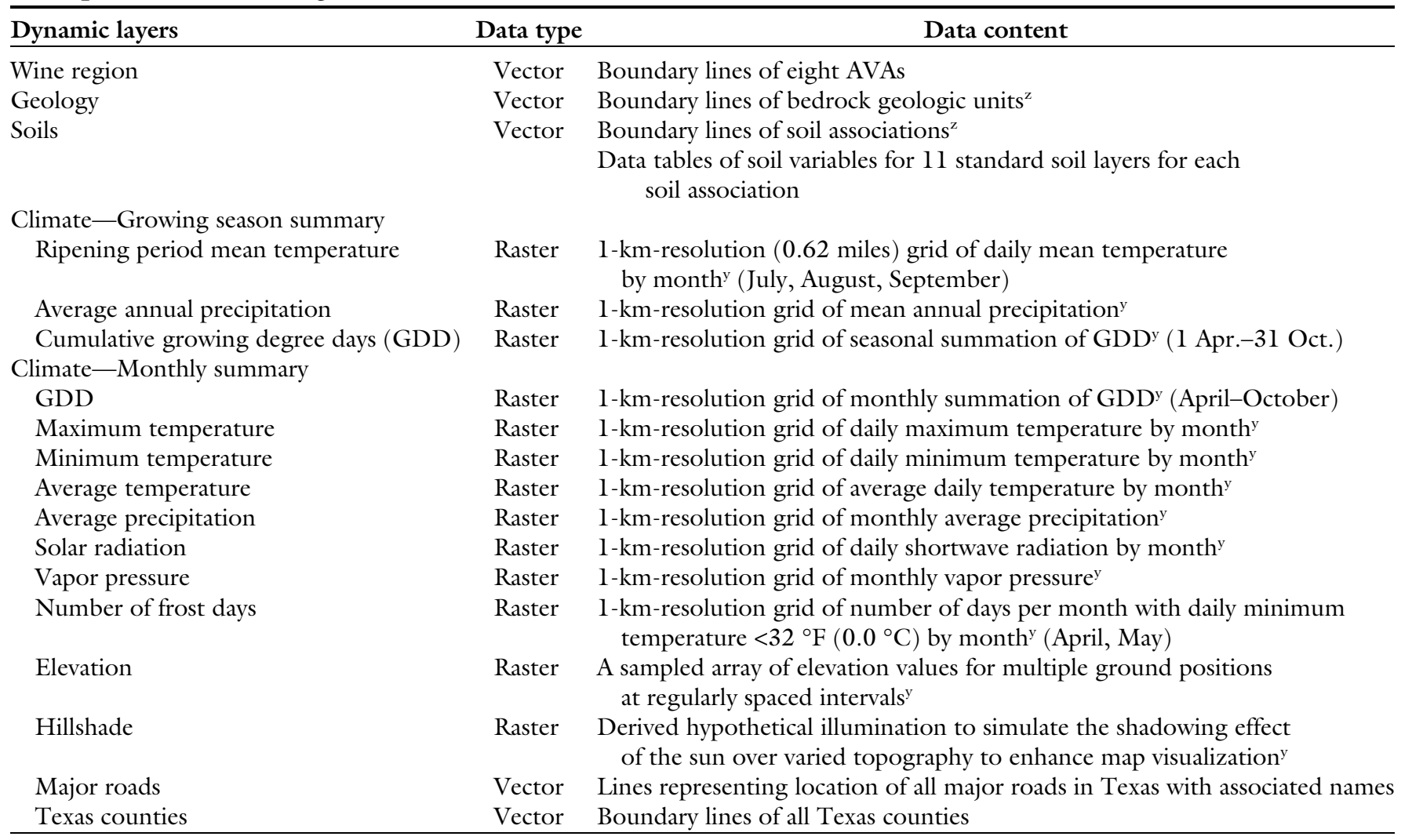

${ }^{z}$ Layer clipped to the full extent of each of the eight Texas AVAs.

${ }^{y}$ Mean value for each pixel location within a Texas AVA. Data derived from Daymet (Thornton et al., 1997).

Table 2. Units of measure and calculation method of climatic variables used in dynamic data layers comprising the AVATXIS geographic information system developed to describe the eight American Viticultural Areas of Texas.

\begin{tabular}{|c|c|c|}
\hline Climatic variable & Unit $^{\mathrm{z}}$ & Calculation method \\
\hline Daily minimum temperature (TMIN) & ${ }^{\circ} \mathrm{F}$ & Average low temperature in $24-\mathrm{h}$ period for a month \\
\hline Growing degree days (GDD) & ${ }^{\circ} \mathrm{F}$ & $\begin{array}{l}\left.\mathrm{GDD}_{\text {Season }}=\Sigma_{\text {April-October }}\left[\left(\mathrm{TAVG}_{\text {Month }}\right)-50^{\circ} \mathrm{F}\right] \times\left(\text { Days }_{\text {Month }}\right)\right] \\
\text { Growing season (April-October) sum and monthly totals }\end{array}$ \\
\hline Ripening period mean temperature (RPMT) & ${ }^{\circ} \mathrm{F}$ & RPMT $=$ TAVG $_{\text {month }}($ July, August, September $)$ \\
\hline Vapor pressure & $\mathrm{Pa}$ & Average daily vapor pressure for individual month \\
\hline Number of frost days & no. & $\begin{array}{l}\text { Number of days per month (April, May) with daily minimum } \\
\text { temperature }<32^{\circ} \mathrm{F}\end{array}$ \\
\hline
\end{tabular}

${ }^{\mathrm{z}}\left({ }^{\circ} \mathrm{F}-32\right) 1.8={ }^{\circ} \mathrm{C}, 1 \mathrm{~cm}=0.3937$ inch, $\mathrm{l} \mathrm{J}=0.2388$ calorie, $1 \mathrm{~Pa}=0.01 \mathrm{mbar}$.

Survey Geographic (SSURGO) and State Soil Geologic (STATSGO). SSURGO operates at a scale from $1: 12,000$ to $1: 63,360$ and provides a detailed level of information derived from field studies and local soil surveys. SSURGO data are used to create statistical summaries or attribute tables for the characterization of an entire map unit. This level of detail is better suited for site selection and not general description of a region as required for the Texas AVA project. STATSGO is a general soil association map, developed by the National Cooperative Soil Survey, which consists of georeferenced map data and its associated attribute tables (U.S. Department of Agriculture, 1994). It was developed at a scale of 1:250,000 using combinations of detailed soil maps, transects, and LANDSAT (Land remote sensing satellite system) images. STATSGO was selected for description of Texas AVAs because it is best suited for describing general soil patterns exhibited within AVAs that often span several counties.

Soil classification in STATSGO is done by name or associations using an alphanumeric map unit ID (MUID) as the common link between soil map units and the corresponding soil map unit name. The dominant soils making up the landscape are depicted by delineations. The soil map unit data 
set consists of closed polygons that are generally geographic mixtures of groups of soils and nonsoil areas. A MUID uniquely identifies each closed delineation (polygon). Each MUID is linked to a unique map unit name, called the soil association. An attribute database gives the proportionate extent of the component soils in the association and soil properties, which includes texture, depth, available water capacity, $\mathrm{pH}$, permeability, and bulk density. Table 3 outlines the soil properties and units of measure derived from STATSGO included in our database. Only certain soil attributes were needed to establish our GIS soil layers, and these attributes are contained in several different STATSGO tables. Numerous links and relates were established using Access 2007 (version 12.0.6606.1000; Microsoft Corp., Redmond, WA) to assemble data tables, which were imported into ArcGIS as a single Access 2007 soil attribute table.

TopograPhic DATA. Topographic data were obtained from the seamless national elevation data set at $10-\mathrm{m}$ resolution (U.S. Geological Survey, 2013). Downloads of these national base layers are available as DEMs in raster format. DEMs are layered with information on elevation for any location in the United States. Because of the large size of the data sets, data were obtained in sections containing the eight Texas AVAs. ArcMap was used to calculate hill shade values with the use of elevation grids and the spatial analyst function.

Geological data. Geological data were obtained from the geological survey of the conterminous United States as a vector layer (Esri shapefile) of bedrock geologic units in polygon format (U.S. Geological Survey, 2012). An associated attribute table provides descriptions of the geologic units mapped to the related spatial polygons. Data were processed using ArcMap by clipping data to the state of Texas and subsequently to each AVA.

System CONFIGURATION. The GIS resource developed to characterize the Texas wine growing regions, named AVATXIS, was constructed around the ArcGIS Server (version 9.3.1, Esri). Development steps involved configuration and publishing AVATXIS as a bundle of eight map "services." A service is ArcGIS terminology for the visual representation of a GIS resource that a server is making available to other computers on a network (e.g., Internet). ArcGIS Desktop (version 9.3.1, Esri) was used to configure AVATXIS as eight separate services, each representing one of the Texas AVAs. Each service was developed with identical data layers of the climate, soil, and topographic features corresponding to the individual winegrowing region. AVATXIS was subsequently published with ArcGIS Server as a bundle of eight independently operating services. Each service represents AVA data as interactive maps and can be publicly accessed via a standard web browser. Figure 2 is a simplified diagram of the AVATXIS system architecture and workflow. Data are stored in databases and accessed by the GIS Server to author and manage maps in response to requests made through the web server by an individual using a standard web browser on the Internet.

A web site, the Winegrowing Regions of Texas, was created as the public portal for access to spatial environmental data compiled for the eight Texas AVAs (Takow et al., 2012). Web site content was developed to provide the user with interpretive descriptions of the AVAs and supporting information to enhance the user experience. Content pages include brief general description of each AVA; technical summary of each AVA; general overview of GIS; definition of an AVA; descriptions of each data element grouped by climate, soils, and topography; and a help section with web site navigation and GIS user instructions. Links were created to seamlessly enter the interactive GIS system (AVATXIS) for detailed spatial exploration of each AVA, enabling display of user-selected data for any location of interest within an AVA.

\section{Results and discussion}

Spatially explicit environmental data relevant to wine grape production were obtained from multiple sources, then processed and assembled as layers of information within a GIS to produce a publicly accessible web-based system to characterize the AVAs of Texas. The general structure of the system (Fig. 3) comprises an interpretive web site (Winegrowing Regions of Texas) and an interactive GIS system (AVATXIS).
Table 3. Soil variables and units of measure used in the soil data layer within the AVATXIS geographic information system developed to describe the eight American Viticultural Areas of Texas.

\begin{tabular}{|c|c|}
\hline Soil variable & Unit $^{\mathrm{z}}$ \\
\hline Depth & $\mathrm{cm}$ \\
\hline Texture & Classification $^{y}$ \\
\hline $\begin{array}{l}\text { Available water } \\
\text { capacity }\end{array}$ & $\mathrm{cm}$ \\
\hline Permeability & $\mathrm{cm} \cdot \mathrm{h}^{-1}$ \\
\hline Bulk density & $\mathrm{g} \cdot \mathrm{cm}^{-3}$ \\
\hline $\mathrm{pH}$ & $\begin{array}{l}\text { Hydrogen ion } \\
\text { concentration }\end{array}$ \\
\hline
\end{tabular}

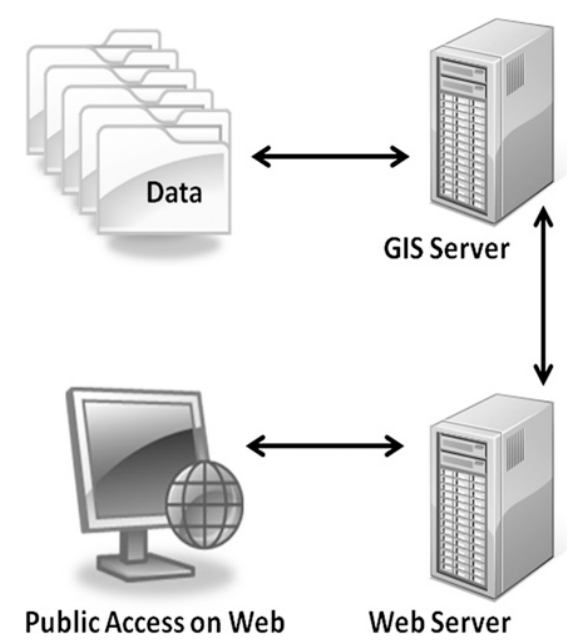

Fig. 2. Flowchart of the AVATXIS geographic information system (GIS) architecture and process. Descriptive data are stored and accessed by the GIS Server to produce maps in response to requests made through the web server by an individual using a web browser on the Internet.

As the portal for information access, the Winegrowing Regions of Texas web site provides the user with options to match the depth and breadth of their information needs. Figure 4 shows the web site home page; menu items and links indicate the available features and functions. Users can access introductory-level explanations of GIS and the AVA appellation system, and the relevance of environmental data to wine grape production. Short descriptions of the eight Texas AVAs provide an overview of the notable characteristics of each winegrowing region. A more detailed narrative description of each 


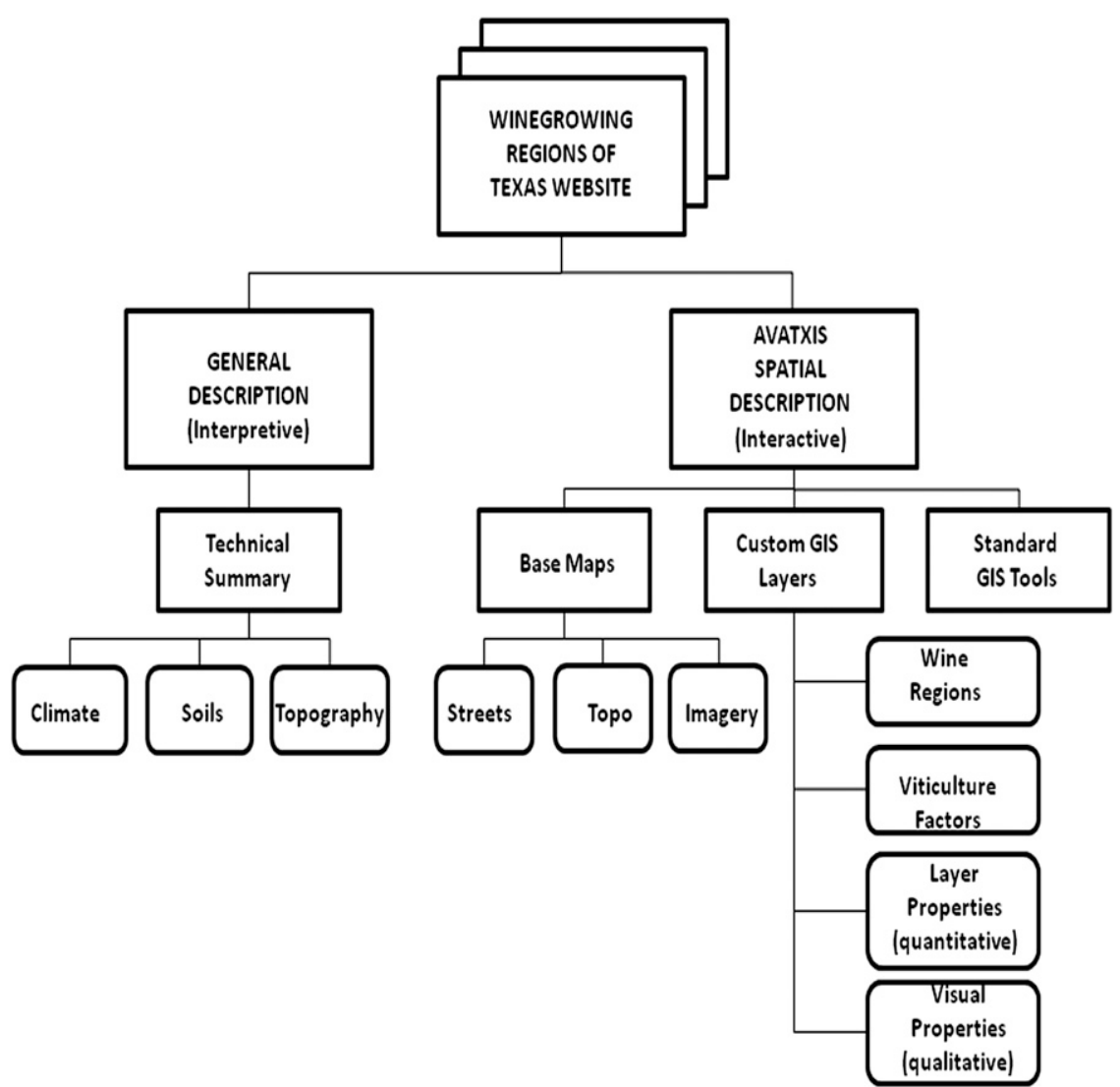

Fig. 3. Schematic overview of interpretive and interactive options for accessing environmental data describing the eight American Viticultural Areas (AVAs) of Texas. From the Winegrowing Regions of Texas web site, the user can opt for a brief general description of the AVA or access the AVATXIS geographic information system for detailed interactive exploration of the AVA.
AVA is available in a technical summary, which also includes data for the regions' topography, soils, and climate. In-depth examination of the spatial variation of environmental factors and their interrelationships within the AVAs can be visualized and analyzed by entering the GIS (AVATXIS).

The interactive functionality of AVATXIS enables a user to "publish" (dynamically generate) custom maps by selecting data layers of interest from a menu. Each map is composed of base layers and dynamic (custom) layers. Base layer options are streets, topography, and satellite imagery, which can be adjusted for transparency or turned on and off at the user's discretion. Dynamic layers are those created specifically for this project (Table 1), which includes AVA boundaries, numerous climatic variables and indices, geology, soils, elevation, and hillshade. Figure 5 shows AVATXIS displaying a map of the Texas Hill Country AVA; note that satellite imagery is the base layer, whereas wine region and average annual precipitation have been selected as dynamic layers from the menu on the right. Selecting the Legend tab on the menu provides the range of data and a color-coded key to spatial variants of the selected dynamic layers

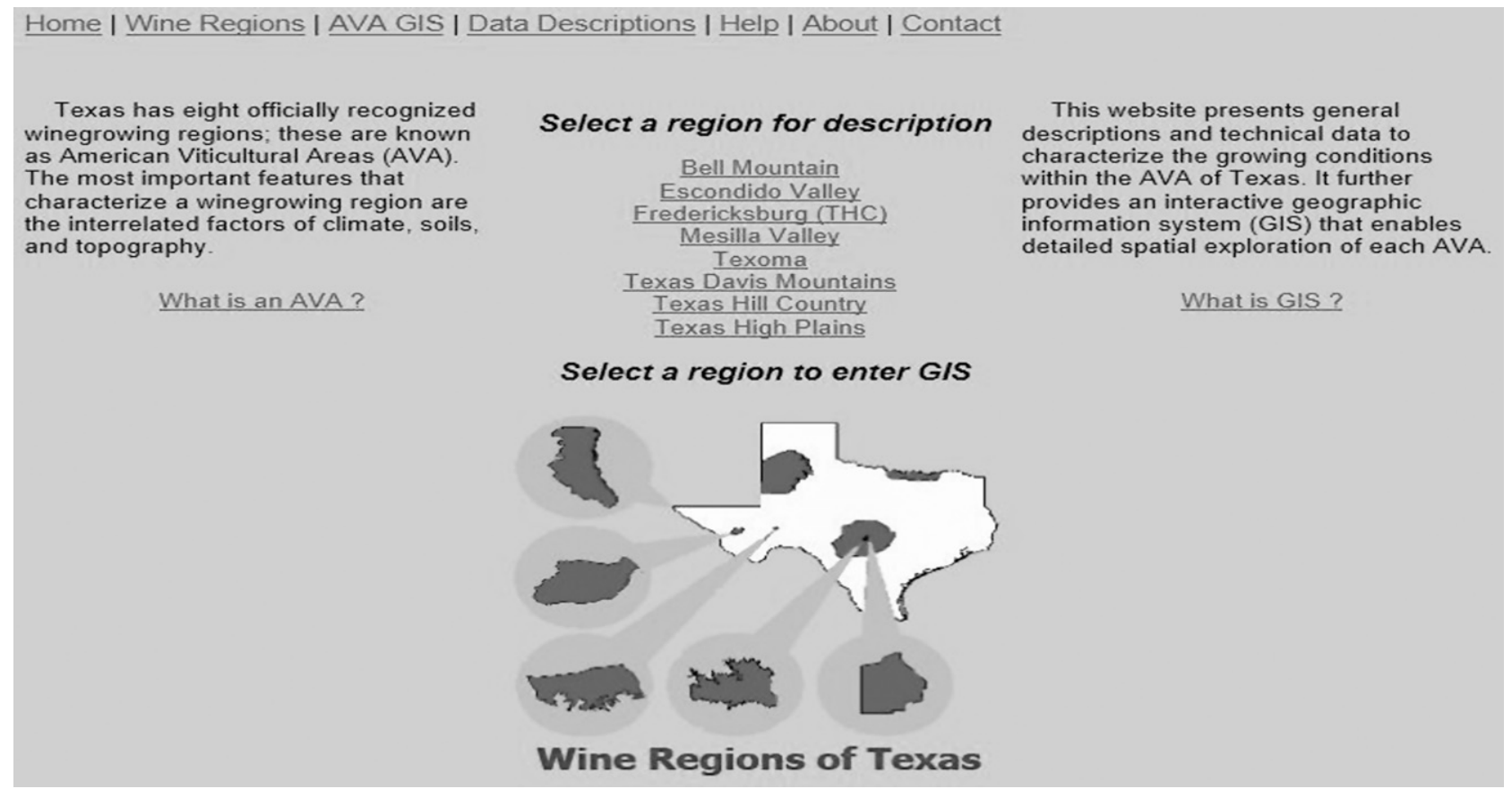

Fig. 4. Home page of the Winegrowing Regions of Texas web site containing hyperlinks to introductory-level explanations of geographic information systems (GIS) and the American Viticultural Areas (AVAs) appellation system, descriptive interpretations of the eight AVAs of Texas, and the AVATXIS GIS for detailed interactive exploration of an AVA. 


\section{Research Reports}

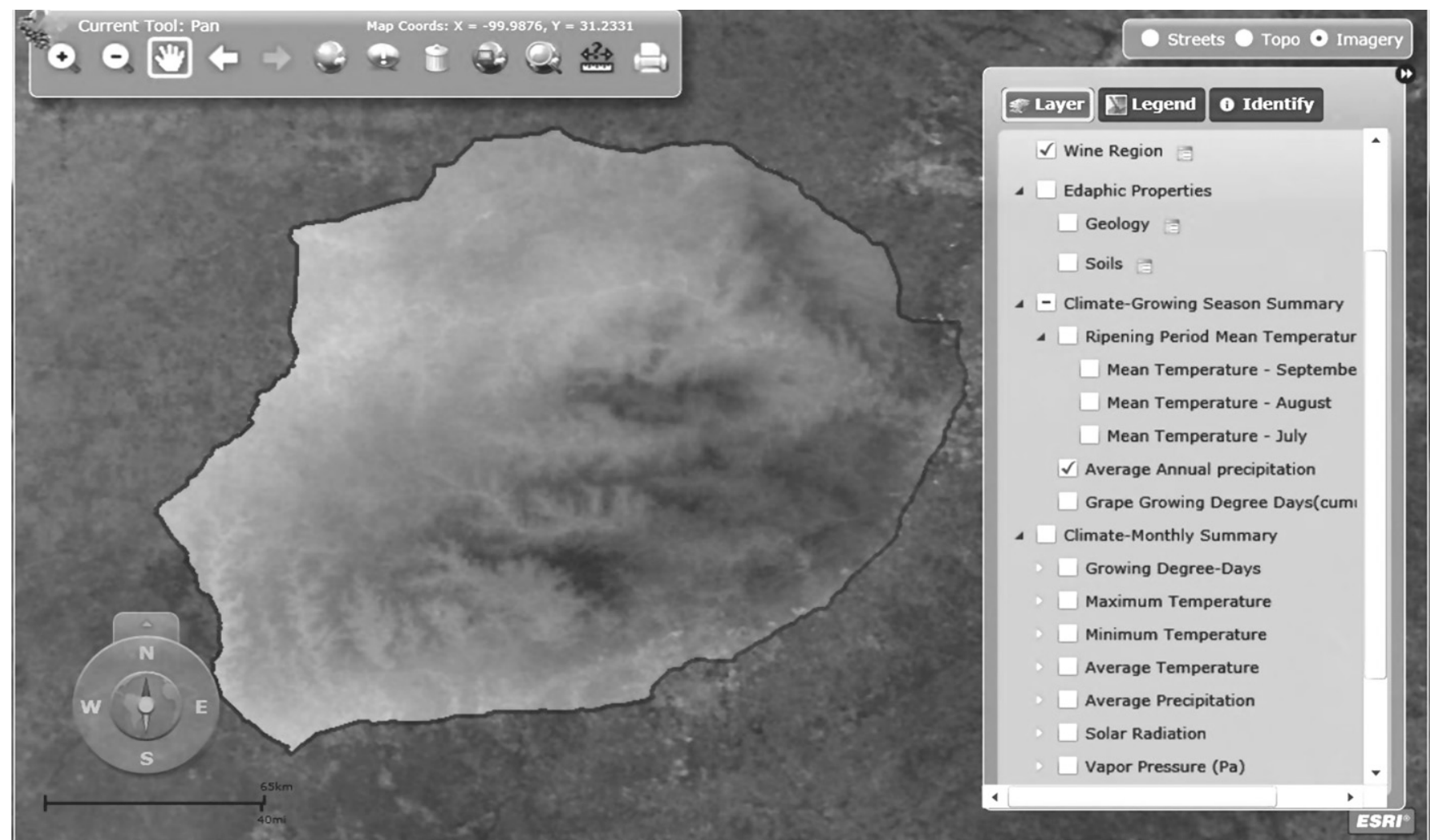

Fig. 5. Map produced by the AVATXIS geographic information system displaying the spatial variation of average annual precipitation in the Texas Hill Country American Viticultural Area. Layer menu on the right displays additional selectable variables for geology, soil, and climate; $1 \mathrm{~Pa}=0.01 \mathrm{mbar}$.

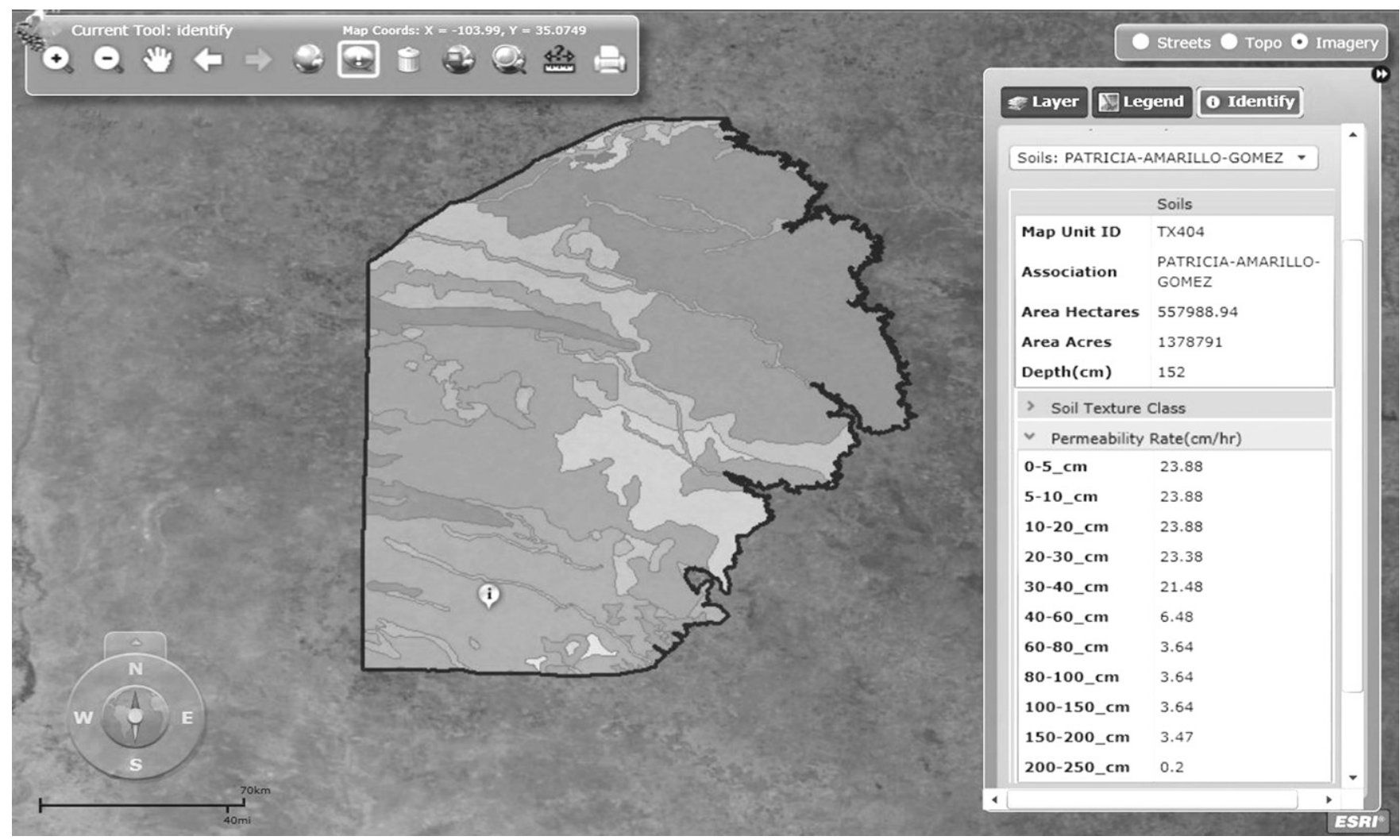

Fig. 6. Map produced by the AVATXIS geographic information system displaying the spatial variation of soil associations in the Texas High Plains American Viticultural Area. Identify menu on the right displays soil data for the specific user-selected location indicated by the "i $\mathrm{i}$ " symbol; $1 \mathrm{~cm}=0.3937$ inch. 
(e.g., average annual precipitation). These data along with visual interpretation of spatial variability on maps enable the user to characterize an AVA for any or all of the environmental factors represented by dynamic layers, and to examine spatial relationships among factors. AVATXIS was used in this way to extract spatial environmental data to characterize and compare the four west Texas AVAs (Hellman et al., 2011)

The toolbar provides additional functionality to interact with data by zooming in and out, panning across a region, measuring objects, and printing maps. Dynamically updated coordinates are shown on the toolbar indicating the cursor position as it is moved across the map. Locationspecific data are obtained with use of the identify feature by placing the cursor on the location of interest and clicking on the active layer displayed on the map.

Figure 6 shows the Texas High Plains soils map with a specific location selected with the identify tool, indicated by the "i" symbol on the map. Selecting the Identify tab from the menu provides the name of the soil association (e.g., Patricia-AmarilloGomez) corresponding to the selected location, as well as the depth to bedrock and total area within the AVA occupied by the soil association. Dropdown submenus display soil association data by depth for texture, permeability (menu expanded for this attribute in Fig. 6), bulk density, $\mathrm{pH}$, and available water capacity.

GIS technology provides an effective tool for visualization and assessment of spatial variability within and between multiple environmental factors important to wine grape production. Web-based delivery of GIS extends the accessibility of environmental data to the public. Spatially explicit data sets of climatic, edaphic, topographic, and other environmental variables are increasingly available for construction of GIS with viticultural applications. The Winegrowing Regions of Texas web site delivers both interpretative descriptions of Texas AVAs based on spatial environmental data sets and an interactive GIS enabling individual investigation of climate, soil, and topographic factors characterizing Texas wine regions.

\section{Literature cited}

Blanco-Ward, D., J.M. Garcia Queijeiro, and G.V. Jones. 2007. Spatial climate variability and viticulture in the Miño River Valley of Spain. Vitis 46:63-70.

Bowen, P.A., C.P. Bogdanoff, B.F Estergaard, S.G. Marsh, K.B. Usher, C.A.S. Smith, and G. Frank. 2005. Geology and wine 10: Use of geographic information system technology to assess viticultural performance in the Okanagan and Similkameen valleys, British Columbia. Geoscience Can. 32:161-176.

Gladstones, J. 1992. Viticulture and environment. Winetitles, Adelaide, Australia.

Gladstones, J. 2011. Wine, terroir and climate change. Wakefield Press, Kent Town, South Australia.

Hellman, E.W., E.A. Takow, M.D. Tchakerian, and R.N. Coulson. 2011. Geology and wine 13. Geographic information system characterization of four appellations in west Texas, USA. Geoscience Can. 38:6-20.

Jones, G.V., A.A. Duff, A. Hall, and J.W. Myers. 2010. Spatial analysis of climate in winegrape growing regions in the western United States. Amer. J. Enol. Viticult. 61:313-326.

Jones, G.V. and E.W. Hellman. 2003. Site assessment, p. 44-50. In: E.W. Hellman (ed.). Oregon viticulture. Oregon State Univ. Press, Corvallis, OR.

Lakso, A.N., K. Kwasnowski, and N. Krause. 2010. New York vineyard site evaluation system. 17 Aug. 2012. <https://www.nyvineyardsite.org >.

Nuñez, J.C.H., S. Ramazzotti, F. Stagnari, and M. Pisante. 2011. A multivariate clustering approach for characterization of the Montepulciano d'Abruzzo Colline Teramane area. Amer. J. Enol. Viticult. 62:239-244

Park, Y.L., T.M. Perring, R.K. Krell, J.M. Hashim-Buckey, and B.L. Hill. 2011. Spatial distribution of pierce's disease related to incidence, vineyard characteristics, and surrounding land uses. Amer. J. Enol. Viticult. 62:229-238.

Penn State Cooperative Extension. 2009. Vineyard map. 17 Aug. 2012. <http:// vineyardmap.psu.edu>.

Perry, R.L. and H.H. Bowen. 1974. Feasibility study for grape production in Texas. Texas Agr. Expt. Sta. Texas A\&M Univ., College Station, TX.

Reynolds, A.G., I. Senchuk, C. van der Reest, and C. de Savigny. 2007. Use of GPS and GIS for elucidation of the basis for terroir: Spatial variation in an Ontario
Riesling vineyard. Amer. J. Enol. Viticult. 58:145-162.

Takow, E.A., E.W. Hellman, A.G. Birt, M.D. Tchakerian, R.N. Coulson, and S. Prabhu. 2012. Winegrowing regions of Texas. 15 Nov. 2012. <http://txwineregions. tamu.edu/>.

Thornton, P.E., S.W. Running, and M.A. White. 1997. Generating surfaces of daily meteorological variables over large regions of complex terrain. J. Hydrol. (Amst.) 190:214-251

U.S. Department of Agriculture. 1993. Soil survey manual. Hdbk. 18. U.S. Dept. Agr., Soil Conservation Serv., Washington, DC.

U.S. Department of Agriculture. 1994. State soil geographic (STATSGO) data base: Data use information. Miscellaneous publication number 1492. U.S. Dept. Agr., Natural Resources Conservation Serv., Fort Worth, TX.

U.S. Geological Survey. 2012. Geology of the conterminous United States. 10 Aug. 2012. <http://tin.er.usgs.gov/geology/ us $>$.

U.S. Geological Survey. 2013. The national map: Elevation. 7 Aug. 2012. <http:// nationalmap.gov/elevation.html>.

U.S. National Archives and Records Administration. 1985. Code of Federal Regulations, Title 27. Alcohol, tobacco products and firearms. Section 9.100. Mesilla Valley. 12 Sept. 2012. <http://www.ecfr. gov $/$ cgi-bin $/$ text $-i d x$ ? $c=$ ecfr $\& S I D=$ ef26bfa229a674a083e8d30d8576d058 $\& \mathrm{rgn}=$ div $8 \&$ view $=$ text $\&$ node $=27: 1.0 .1$. 1.7.3.41.80\&idno $=27$.

U.S. National Archives and Records Administration. 1986. Code of Federal Regulations, Title 27. Alcohol, tobacco products and firearms. Section 9.55. Bell Mountain. 12 Sept. 2012. <http://www. ecfr.gov $/$ cgi-bin $/$ text-idx? c=ecfr $\&$ SID $=$ ef26bfa229a674a083e8d30d8576d058 \&rgn $=$ div $8 \& v i e w=$ text $\&$ node $=27: 1.0 .1$. 1.7.3.41.35\&idno $=27>$.

U.S. National Archives and Records Administration. 1988. Code of Federal Regulations, Title 27. Alcohol, tobacco products and firearms. Section 9.125. Fredericksburg in the Texas Hill Country. 12 Sept. 2012. <http://www.ecfr. gov/cgi-bin $/$ text-idx? $\mathrm{c}=\mathrm{ecfr} \& S I D=$ ef26bfa229a674a083e8d30d8576d058 \&rgn=div8\&view=text\&node=27:1.0.1.1. 7.3.41.105\&idno $=27>$.

U.S. National Archives and Records Administration. 1992. Code of Federal Regulations, Title 27. Alcohol, tobacco products and firearms. Section 9.141. Escondido Valley. 12 Sept. 2012. <http://www.ecfr. gov/cgi-bin $/$ text - id $x$ ? c $=$ ecfr $\& S I D=$ 


\section{Research Reports}

ef26bfa229a674a083e8d30d8576d058\& rgn=div8\&view=text\&node=27:1.0.1.1. 7.3.41.121\&idno=27>.

U.S. National Archives and Records Administration. 1993a. Code of Federal Regulations, Title 27. Alcohol, tobacco products and firearms. Section 9.136. Texas Hill Country. 12 Sept. 2012.<http:// www.ecfr.gov/cgi-bin/text-idx?c=ecfr\& $\mathrm{SID}=$ ef26bfa229a674a083e8d30d8576 d058\&rgn $=$ div $8 \&$ view $=$ text \&node $=27$ : 1.0.1.1.7.3.41.116\&idno=27>.

U.S. National Archives and Records Administration. 1993b. Code of Federal Regulations, Title 27. Alcohol, tobacco products and firearms. Section 9.144. Texas High Plains. 12 Sept. 2012. <http:// www.ecfr.gov/cgi-bin/text-idx?c=ecfr \& $\mathrm{SID}=$ ef26bfa229a674a083e8d30d8576 $\mathrm{d} 058 \&$ rgn $=$ div $8 \&$ view $=$ text $\&$ node $=27$ : 1.0.1.1.7.3.41.124\&idno=27>.

U.S. National Archives and Records Administration. 1998. Code of Federal Regulations, Title 27. Alcohol, tobacco products and firearms. Section 9.155. Texas Davis Mountains. 12 Sept. 2012. <http://www. ecfr.gov/cgi-bin/text-idx? c=ecfr $\&$ SID $=$ ef26bfa229a674a083e8d30d8576d058\& rgn=div8\&view=text\&node=27:1.0.1.1. 7.3.41.135\&idno=27>.
U.S. National Archives and Records Administration. 2005. Code of Federal Regulations, Title 27. Alcohol, tobacco products and firearms. Section 9.185. Texoma. 12 Sept. 2012. <http://www. ecfr.gov/cgi-bin/text-idx? c=ecfr \&SID = ef26bfa229a674a083e8d30d8576d058\& rgn=div8\&view=text\&node=27:1.0.1.1.7. 3.41.165\&idno $=27>$.

White, R.E. 2009. Understanding vineyard soils. Oxford University Press, Oxford, UK.

Winkler, A.J., J.A. Cook, W.M. Kliewer, and L.A. Lider. 1974. General viticulture. 4th ed. Univ. of California Press, Berkeley, CA. 